\section{Abd-Elrahman ${ }^{1}$}

\title{
A REVIEW OF TELECOMMUNICATIONS SERVICE QUALITY DIMENSIONS
}

Abstract: The purpose of this paper is to review the service quality dimensions established in various empirical studies conducted across the world specifically applied to telecommunications services. This paper reviews only empirical studies based on survey data and statistical methods of analysis since 2001 till 2017. The aim of this critical review of the different service quality models is to identify the various dimensions which emerged out of the studies, compare the commonality between them and highlight the limitations of the studies. The findings revealed that the meaning of service quality may have some global aspects, as shown by the similarities in the core dimensions proposed in the different studies. This paper supports to the contention that the dimensionality of SERVQUAL and importance of the dimensions vary with the cultural and country context even within the telecommunications industry. It identifies eight service quality dimensions in the telecommunications services - reliability, tangibles, responsiveness, assurance, empathy, network, customer service and convenience. The findings are valuable to academics and practitioners in providing a direction for service quality improvement by indicating the common theme that emerges from the service quality models.

Keywords: Telecommunications service quality, SERVQUAL, Customer services quality, Measure, Review

\section{Introduction}

Over the past few decades service quality has drawn a lot of attention from researchers and practitioners due to its strong impact on organizational performance, customer satisfaction, customer loyalty and profitability. Service quality is often understood as a measure of how well the level of the delivered services matches the expectations of customers (Santos, 2003). As an example, the definition of Grönroos (1984) outlines perceived service quality, as "the outcome of an evaluation process,

\footnotetext{
${ }^{1}$ Corresponding author: Abd-Elrahman Email: abdohassanein123@gmail.com
}

where the consumer compares his expectations with the service he perceives he has received". Additionally, Parasuraman et al. (1988) defined service quality as "the overall evaluation of a specific service firm that results from comparing that firm's performance with the customers' general expectations of how firms in that industry should perform".

Unlike goods quality, which can be measured with some objectivity, service quality (SQ) is elusive and abstract. The unique features of services such as inseparability of production and consumption, intangibility, heterogeneity, 
and perishability make measurement of quality a very complex matter Parasuraman et al. (1988). As a result of the absence of objective measures, firms must depend on consumers' perceptions of service quality to determine their strengths and/or weaknesses, and put appropriate strategies. This makes development of managerially useful and psychometrically sound scales to measure service quality very important.

Service quality plays a vital role in a firm's competitive advantage (Storbacka et al., 1994; Roberts et al., 2003). Services research has widely examined the measurement of service quality to help practitioners successfully manage the delivery of quality service (e.g., Grönroos, 1984; Parasuraman et al., 1988; Cronin and Taylor, 1992). Service quality is measured to evaluate service performance, identify service problems, manage service delivery, and as a basis for corporate and employee rewards (Parasuraman et al., 1988).

The conceptualization and measurement of the service quality construct has been dominated by the use of the SERVQUAL scale introduced by Parasuraman et al. (1988). The SERVQUAL scale proposes a gap-based comparison of the expectations and performance perceptions of consumers. This measurement model is similar to the disconfirmation model traditionally used to assess consumer satisfaction (see Cronin and Taylor, 1992). Grönroos' (1984) service quality model was the first attempt, and later other researchers proposed their own conceptualizations (e.g. Parasuraman et al., 1985, 1988, Cronin and Taylor, 1992; Dabholkar et al.,1996; Brady and Cronin, 2001). All these models share a common feature: They propose a multidimensional service quality conceptualization that it is essentially linked to the measurement of consumer quality perceptions. Therefore, service quality measurement models offer a framework for understanding what service quality is, as well as how to measure service quality in each proposed conceptualization.

Recently, the interest in conceptualizing and measuring service quality in the mobile telecommunications sector increased due to the quick increase of penetration rates in most countries around the world and rapid technological advances. Van der Wal et al. (2002) used SERVQUAL to measure service quality in a mobile telecommunications company in South Africa. Their results confirmed that the instrument could be used to evaluate service quality in that industry. SERVQUAL was also employed by Johnson and Sirikit (2002) to investigate service quality perceptions in the Thai telecommunications industry. The results showed that the instrument is recommended for process-driven service firms such as banking, retailing, telecommunications and health care. Another stream of research aimed to develop service quality conceptualization and measurement models by targeting specifically the mobile telephony sector (Kim et al., 2004; Aydin and Ozer, 2005; Kuo et al., 2009; Lu et al., 2009; Negi, 2009; Santouridis and Trivellas, 2010; Ozer et al., 2013; Liang et al., 2013; Huang et al., 2015). The models developed suggest several dimensions, whose definitions and meaning overlap to a great extent. The aim of this paper is to review the service quality dimensions and models established in various empirical studies conducted across the world specifically applied to telecommunications services.

\section{Need for present study}

Recently, globalization and liberalization are affecting economies of not only developing, but also developed countries. Organizations are also changing their focus areas from profit maximization to maximizing profits through increased customer satisfaction. The competition pressures are forcing the organizations to not only look at the processes, but also on the way they are delivered. Over the past two decades, business scenario has changed significantly. Some of the key changes that have taken 
place in the business are (Sangeetha and Mahalingam, 2011):

- horizontal business processes replacing vertical functional approach;

- greater sharing of information with all connected links and customers;

- greater emphasis on organizational and process flexibility;

- necessity to coordinate processes across many sites;

- employee empowerment and the need for rules-based real-time decision support systems;

- competitive pressure to introduce new service/products more quickly;

- integrated customer-driven processes;

- quick response to customers' needs;

- worldwide relationships between various trade partners, suppliers, etc.;

- easily accessible information through internet;

- flexible and efficient service/product customization; and

- The tremendous development in the field of communication and information technology

Owing to the factors like open markets, increase in use of IT, increased customer knowledge and awareness, etc. it becomes a must to deliver the services better than competitors at agreed price. In this context, the subject of service quality needs a new understanding in the current business scenario. This study can help to identify the various general models applicable for telecommunications. It is also aimed to review the models specifically developed for the telecommunications industry, their strengths and limitations. This study thus attempts to provide benefits to practicing managers and researchers by compiling a large amount of information on service quality in telecommunications at one place.

\section{Perceived Service Quality}

Perceived service quality can be defined as "a global judgment or attitude relating to the superiority of a service relative to competing offerings" (Parasuraman et al., 1988, p. 16). Perceptions pertain to consumers' beliefs concerning the utility emanating from services which they experienced (Parasuraman et al., 1985). Previous researches have demonstrated that perceived service quality from the consumer's perspective often differs from the producer's evaluation and is a critical factor in predicting shopping behavior (Grönroos, 1984).

Another aspect Jiang and Wang, (2006) pointed out that, evaluations are not based on service attributes; rather these depend on a customer's feelings or memory. So, customers measure service quality in terms of how much pleasure they have received from a service. Jiang and Wang, (2006) concluded that the role of perceived service quality in customer satisfaction is established but the conditions under different dimensions of effect will or will not influence service quality evaluation and customer satisfaction.

Ueltschy et al. (2007) revealed while comparing US and Japan in context that high performance will lead towards high expectations which will eventually yield high customer satisfaction and high perceived service quality. Omachonu et al. (2008) explained that according to the American Customer Satisfaction Index (ACSI), customer expectations are evaluated by asking the customer to recall the level of quality they expected on the basis of their knowledge about service or goods and actual experience with a goods or services.

\section{Dimensions of Quality}

"Quality" is not a singular but a multidimensional phenomenon; and the term "Quality" is widely used as a measure of 
excellence (Madu and Madu, 2002). It is not possible to ensure product or service quality without determining the salient aspects of "quality". The genetic dimensions of "service quality" are identified and discussed in this section. The utility value of these determinants is situation-dependent.

Grönroos, (1984) argued that "service quality" comprises of three dimensions. These are:

(1) The technical quality of outcome. That is to say, the actual outcome of the service encounter. The service outcome can often be measured by the consumer in an objective manner.

(2) The functional quality of the service encounter. This element of "quality" is concerned with the interaction between the provider and recipient of a service and is often perceived in a subjective manner.

(3) The corporate image. This is concerned with consumers' perceptions of the service organization. The image depends on: technical and functional quality; price; external communications; physical location; appearance of the site; and the competence and behavior of service firms' employees.

Lehtinen and Lehtinen, (1982) also contend that "service quality" has three dimensions:

(1) Physical quality. This includes such items as the condition of buildings and enabling equipment.

(2) Corporate quality. This refers to the organization's image and profile.

(3) Interactive quality. This derives from the interaction between service organizations' personnel and the customer as well as the interaction between customers.

Lehtinen and Lehtinen argue that in examining the determinants of quality it is necessary to differentiate between the quality associated with the process of service delivery and the quality associated with the outcome of the service. This is a useful separation and it is taken into account in reviewing the determinants of "service quality". These attempts to identify the service quality determinants suffer from lack of sufficient detail. Their most significant contribution is to divide service "quality" into quality of process and quality of outcome. Other researchers and interested organizations have suggested a more detailed classification.

Garvin, (1987) identified eight key attributes that a product or service must have to be considered of high quality. These attributes, referred to as dimensions of quality, are:

(1) Performance - deals with the primary purpose of the product or service or how well the product or service is achieving its objective.

(2) Features - deals with added touches, bells, and whistles or secondary characteristics that the product or service possesses or extra features present in the product or service.

(3) Reliability - measures the consistency of performance of the product or service over time.

(4) Durability - measures the useful life of the product or service.

(5) Serviceability - deals with the ease of servicing the product when necessary or resolving conflicts and complaints from customers. Many of the issues here deal with service after sales.

(6) Conformance - deals how the product or service satisfies customers' expectations.

(7) Perceived quality - is often referred to as reputation since it is the perceived reputation of the product or service based on past performance and other intangibles that may influence its perceived quality.

(8) Aesthetics - deals with sensory characteristics and outward appearance of the product or service. Characteristics such as feel, looks and sounds are important.

These dimensions have been very well applied in measuring the quality of products and to a lesser extent in measuring the quality of services. Unlike products, services are intangible and may vary from customer to customer. It is more difficult to standardize services and to use the same yardstick for products to measure the quality of services. The quality of service is more or less in the eye of the beholder. 
When the SERVQUAL scale was developed by Parasuraman et al. $(1985,1988)$, their aim was to provide a generic instrument for measuring service quality across a broad range of service categories. Relying on information from 12 focus groups of consumers, Parasuraman et al. (1985) reported that consumers evaluated service quality by comparing expectations (of service to be received) with perceptions (of service actually received) on ten dimensions: (1) Reliability (performance consistency, dependability);

(2) Responsiveness (service timeliness, staff willingness);

(3) Competence

(skills/knowledge

possession to perform services);

(4) Access (the ease of approachability and contact);

(5) Courtesy (staff attitude demeanor);

(6) Communication (informing, listening customers);

(7) Credibility (trustworthiness, honesty);

(8) Security (risk/doubt);

(9) Understanding/knowing the customer;

(10) Tangibles (physical evidence of service)

In a later (Parasuraman et al., 1988) work, the authors reduced the original ten dimensions to five. Some of the dimensions identified here are already in Garvin's eight dimensions of quality. However, Parasuraman et al. (1988) added new dimensions to cover the human element in service quality. Garvin, for example, covered the first three dimensions listed below while the last two are specifically designed for service quality.

(1) Tangibles (the appearance of physical facilities, equipment, and personnel);

(2) Reliability (the ability to perform the promised service dependably and accurately);

(3) Responsiveness (the willingness to help customers and provide prompt service);

(4) Empathy (the provision of individual care and attention to customers); and

(5) Assurance (the knowledge and courtesy of employees and their ability to inspire trust and confidence).

\section{Methods}

\subsection{Literature search}

A literature search was conducted using combination of keywords such as "service quality, SERVQUAL, service quality in telecommunications, service quality in mobile telecommunications, service quality in telecom, service quality in wireless networks" from the literature databases Scienceirect, and Emerald Insight. The studies were limited to empirical English studies based on survey data and statistical methods of analysis and having the service quality construct defined from the customers' perspective. Customer satisfaction studies are omitted from the review as service quality and satisfaction are recognised as different conceptualisations such that service quality evaluations formed prior to satisfaction (Abdel-Rahman, 2012; Santouridis and Trivellas, 2010; Kuo et al., 2009; Wang and Lo, 2002).

This review is not restricted to one article per survey instrument i.e. when more than one article was identified reportedly using the same survey instrument (for e.g. SERVQUAL), all the articles which were found were included for analysis such as Alnsour et al. (2014) and Johnson and sirikit (2002). Also, the review is not confined to one article per country i.e. when more than one article were identified and reported from the same country such as Liang et al. (2013) and $\mathrm{Lu}$ et al. (2009) both were included for the analysis.

The review comprise of 22 studies that are selected from three literature databases "ScienceDirect", "Emerald Insight" and "Springer Link"; and include 18 journals as shown in Table I. The quality dimensions of telecommunications services from the customers' perspective that has resulted from the combination of keyword searches limiting to articles in English are summarized in Table II. The articles are presented in a comparative tabulated form 
based on three categories of information Author(s) and year, Application field and Quality dimensions. They will yield to extensive and close analysis to find out the direction of research in this field.

Table 1. Journals

\begin{tabular}{|l|l|}
\hline $\begin{array}{l}\text { Journal name } \\
\text { Applications }\end{array}$ & 2 \\
\hline International Journal of Bank Marketing & 2 \\
\hline Managing Service Quality & 2 \\
\hline Computer Standards \& Interfaces & 1 \\
\hline Computers in Human Behavior & 1 \\
\hline Decision Support Systems & 1 \\
\hline $\begin{array}{l}\text { Digital Policy, Regulation and } \\
\text { Governance (Info) }\end{array}$ & 1 \\
\hline Electronic Markets & 1 \\
\hline $\begin{array}{l}\text { International Journal of Commerce and } \\
\text { Management }\end{array}$ & 1 \\
\hline $\begin{array}{l}\text { International Journal of Quality \& } \\
\text { Reliability Management }\end{array}$ & 1 \\
\hline Journal of Business Research & 1 \\
\hline Journal of Services Marketing & 1 \\
\hline Management Decision & 1 \\
\hline Marketing Intelligence \& Planning & 1 \\
\hline Procedia - Social and Behavioral Sciences & 1 \\
\hline Production and operations management & 1 \\
\hline Telecommunications Policy & 1 \\
\hline The TQM Journal & 1 \\
\hline
\end{tabular}

Figure (1) displays the numbers of studies per year that measured telecommunications service quality since 2001 till 2017. It is clear that the numbers of studies done during the five years period between 2001 and 2005 is (7); then it decreased to (5) during the next five years; then raised to (6) during the next five years between 2011 and 2015. This means that the attention to measuring the service quality of this vital sector didn't diminish, and the debate around what dimensions should be used is still open. With the development of such handheld devices as personal digital assistants, tablets and smart phones, wireless and mobile technologies and their associated applications have become essential for daily life. Recently, there have been many research projects directed to measure the service quality of new services provided through the technology of mobile networks (e.g. mobile education, mobile health services, mobile commerce, and mobile banking) (Arcand et al., 2017; Huang et al., 2015; Akter et al., 2010).

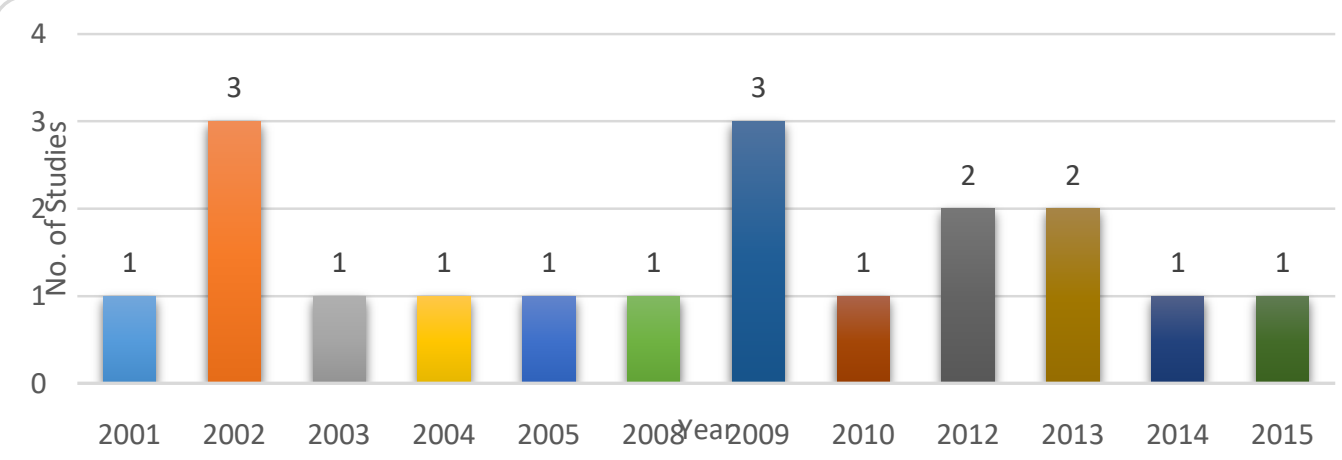

Figure I. Reviewed Studies That Measured Telecommunications Service Quality 


\section{Intermational Quality Conference}

Table 2. A Review of the Telecommunications Service Quality Scales

\begin{tabular}{|c|c|c|}
\hline research & Sector or field & Quality dimensions \\
\hline $\begin{array}{l}\text { Leisen and Vance } \\
\text { (2001) }\end{array}$ & Telecommunications & $\begin{array}{l}\text { (5) dimensions of SERVQUAL: (reliability, tangibles, responsiveness, } \\
\text { assurance, and empathy) }\end{array}$ \\
\hline $\begin{array}{l}\text { van der Wal et al. } \\
(2002)\end{array}$ & $\begin{array}{c}\text { Mobile } \\
\text { telecommunications }\end{array}$ & $\begin{array}{l}\text { (5) dimensions of SERVQUAL: (reliability, tangibles, responsiveness, } \\
\text { assurance, and empathy) }\end{array}$ \\
\hline $\begin{array}{l}\text { Johnson and sirikit } \\
(2002)\end{array}$ & Telecommunications & $\begin{array}{l}\text { (5) dimensions of SERVQUAL: (reliability, tangibles, responsiveness, } \\
\text { assurance and empathy) }\end{array}$ \\
\hline Wang and Lo (2002) & Telecommunications & $\begin{array}{l}\text { (6) dimensions: tangibles, network quality, reliability , responsiveness, } \\
\text { assurance and empathy }\end{array}$ \\
\hline $\begin{array}{l}\text { Athanassopoulos } \\
\text { and Iliakopoulos } \\
\text { (2003) }\end{array}$ & Telecommunications & $\begin{array}{l}\text { (5) dimensions: branch network, billing, corporate image, fault repair, } \\
\text { and service provision }\end{array}$ \\
\hline Kim et al. (2004) & Telecommunications & $\begin{array}{l}\text { (6) dimensions: call quality, pricing structure, mobile device, value- } \\
\text { added services, convenience in procedures, and customer support }\end{array}$ \\
\hline $\begin{array}{l}\text { Aydin and Ozer } \\
(2005)\end{array}$ & Telecommunications & $\begin{array}{l}\text { (6) dimensions: coverage area, customer services, adding service, } \\
\text { vendor, campaign, and advertisement }\end{array}$ \\
\hline $\begin{array}{l}\text { Kumar and Lim } \\
(\mathbf{2 0 0 8})\end{array}$ & $\begin{array}{c}\text { Mobile } \\
\text { telecommunications }\end{array}$ & $\begin{array}{l}\text { (4) dimensions: network quality, data services, billing service, and } \\
\text { customer service }\end{array}$ \\
\hline Kuo et al. (2009) & $\begin{array}{l}\text { Mobile value-added } \\
\text { services }\end{array}$ & $\begin{array}{l}\text { (4) dimensions: customer service and system reliability, navigation and } \\
\text { visual design, content quality, and connection speed }\end{array}$ \\
\hline Negi (2009) & $\begin{array}{c}\text { Mobile } \\
\text { telecommunications }\end{array}$ & $\begin{array}{llll}\text { (7) dimensions: tangibles, reliability, responsiveness, assurance, } \\
\text { empathy, network aspect, and convenience }\end{array}$ \\
\hline Lu et al. (2009) & $\begin{array}{l}\text { Mobile } \\
\text { telecommunications }\end{array}$ & $\begin{array}{l}\text { (10) dimensions classified into three broad categories: interaction quality } \\
\text { (attitude, expertise, problem solving and information), environment } \\
\text { quality (equipment, design and situation) and outcome quality } \\
\text { (punctuality, tangibles and valence) }\end{array}$ \\
\hline $\begin{array}{l}\text { Santouridis and } \\
\text { Trivellas (2010) }\end{array}$ & $\begin{array}{c}\text { Mobile } \\
\text { telecommunications }\end{array}$ & $\begin{array}{l}\text { (6) dimensions: network, value-added services, mobile devices, customer } \\
\text { service, pricing structure, and billing system }\end{array}$ \\
\hline Akter et al. (2010) & $\begin{array}{l}\text { Mobile health } \\
\text { services }\end{array}$ & $\begin{array}{l}\text { (9) dimensions classified into three broad categories: platform quality } \\
\text { (system reliability, system availability, system efficiency, and system } \\
\text { privacy), interaction quality and outcome quality }\end{array}$ \\
\hline Zhao et al. (2012) & $\begin{array}{c}\text { Mobile } \\
\text { telecommunications }\end{array}$ & $\begin{array}{l}\text { (3) dimensions: interaction quality, environment quality, and outcome } \\
\text { quality }\end{array}$ \\
\hline $\begin{array}{l}\text { Abd-Elrahman } \\
(2012)\end{array}$ & $\begin{array}{c}\text { Mobile } \\
\text { telecommunications }\end{array}$ & $\begin{array}{l}\text { (7) dimensions: tangibles, reliability, responsiveness, assurance, } \\
\text { empathy, network aspect, and convenience }\end{array}$ \\
\hline Liang et al. (2013) & $\begin{array}{l}\text { Mobile } \\
\text { telecommunications }\end{array}$ & $\begin{array}{l}\text { (7) dimensions: core service failure, high price, ethical problems, } \\
\text { competition, inconvenience, service encounter failure, and } \\
\text { family/friends/group impact }\end{array}$ \\
\hline Ozer et al. (2013) & Mobile services & $\begin{array}{l}\text { (5) dimensions: availability, perceived risk, easy to use, compatibility of } \\
\text { mobile devices, and entertainment services }\end{array}$ \\
\hline Alnsour et al. (2014) & Telecommunications & $\begin{array}{l}\text { (5) dimensions of SERVQUAL: (reliability, tangibles, responsiveness, } \\
\text { assurance, and empathy) }\end{array}$ \\
\hline $\begin{array}{l}\text { Chen and Yang } \\
(2015)\end{array}$ & Telecommunications & $\begin{array}{l}\text { (13) dimensions classified into three broad categories: system service } \\
\text { quality (efficiency \& effectiveness, functionality, integration, construct } \\
\text { cost and security), information service quality (accuracy, integrity, } \\
\text { usability and readability), and customer service quality (after-sales } \\
\text { service, flexible-price policy, technique support and training) }\end{array}$ \\
\hline Huang et al. (2015) & $\begin{array}{l}\text { Mobile commerce } \\
\text { services }\end{array}$ & $\begin{array}{l}\text { (9) dimensions: efficiency, system availability, content, privacy, } \\
\text { fulfillment, responsiveness, compensation, contact, and billing }\end{array}$ \\
\hline $\begin{array}{l}\text { Jun and Palacios } \\
(2016)\end{array}$ & Mobile banking & $\begin{array}{l}\text { (17) dimensions classified into two broad categories: mobile banking } \\
\text { application quality and mobile banking customer service quality } \\
\text { (continuous improvement, competence, credibility, courtesy, } \\
\text { understanding the customer, communication, reliability, access and } \\
\text { responsiveness). }\end{array}$ \\
\hline Arcand et al. (2017) & Mobile banking & $\begin{array}{l}\text { (5) dimensions classified into two broad categories: utilitarian } \\
\text { dimensions (security/privacy and practicity), and hedonic dimensions } \\
\text { (design/aesthetics, sociality and enjoyment) }\end{array}$ \\
\hline
\end{tabular}




\section{Summary and discussion}

\subsection{Dimensions of the Telecommunications SQ Construct}

The literature review of the telecommunications SQ researches makes it clear that the construct of telecommunications SQ is multidimensional, with the number of reported dimensions ranging from three (Zhao et al., 2012) to thirteen (Chen and Yang, 2015). In case of telecommunications services, the conventional method of measuring service quality was no longer relevant. As a result, research has identified new dimensions of service quality, such as navigation and visual design, ease-of-use, availability, value-added services, network, perceived risk, system service quality, information and content quality.

It is apparent that there is no consensus on the number and the nature of the dimensions of the telecommunications SQ construct identified in previous research. It is true that some dimensions (such as 'reliability' and 'network') appear consistently in the various models, which indicates that there are some common dimensions used by customers in evaluating telecommunications SQ (Alnsour et al., 2014; Santouridis and Trivellas, 2010; Negi, 2009).

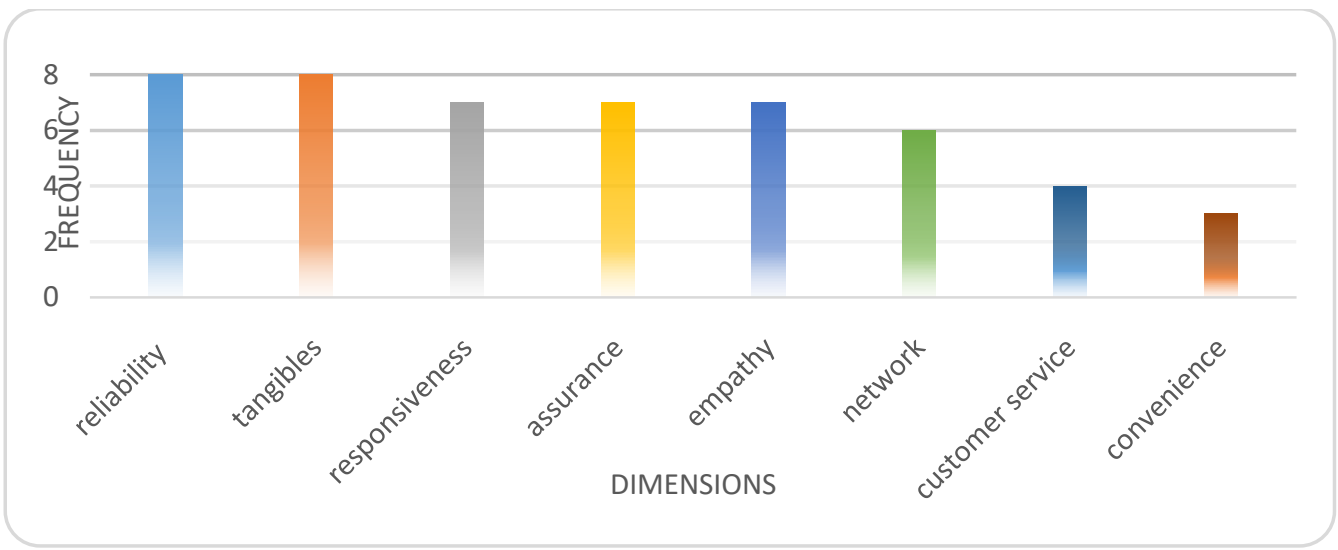

According to Figure (II), among the various dimensions the literature review cites, eight appear consistently: ('reliability', 'tangibles', 'responsiveness', 'assurance', 'empathy', 'network' 'customer service', 'convenience').

The first of these, reliability, which is also one of the prominent dimensions in the traditional SERVQUAL instrument, refers to the performance of a promised service in an accurate and timely manner and to the delivery of intact and correct products (or services) at times convenient to customers (Wang and Lo, 2002). In the researches reviewed here, this dimension is a significant determinant of (i) overall service quality (Negi, 2009, Leisen and Vance, 2001), (ii) satisfaction (Kuo et al., 2009), (iii) perceived value (Kuo et al., 2009), and (iv) customer loyalty (Alnsour, 2014).

The second dimension, tangibles, consists of the physical facilities, equipment and appearance of personnel. Clients often trust the tangible evidence that surrounds the service when making their assessment, as there is no physical element to be assessed in services (Negi, 2009). The reviewed researches revealed that tangibles dimension 
is a significant determinant of customer satisfaction and customer value (Wang and Lo, 2002). It revealed using similar dimensions that express the same meaning like: navigation and visual design and environment quality.

The third of the dimensions that appears consistently in the researches reviewed here is responsiveness, which refers to the willingness and ability of the service provider to meet and adapt to customers' needs (Alnsour, 2014) or to help users and deliver prompt services (Akter et al., 2010), the effectiveness of the site's problemhandling process and return policy (Huang et al., 2015). It was identified as a dimension of M-S-QUAL, which assesses mobile commerce shopping experiences for virtual and physical product. Responsiveness was found to be the dimension that has the greatest impact on loyalty within the Jordanian culture (Alnsour et al. 2014).

The fourth common dimension, assurance (including competence, courtesy, credibility and security), deals with the trust and confidence of the service provider based primarily on the knowledge and courtesy of employees (Alnsour et al., 2014). The literature revealed that assurance dimension is a significant determinant of customer satisfaction (Wang and Lo, 2002). It was used in some telecommunications SQ scales (e.g., Negi, 209; Wang and Lo, 2002; Johnson and Sirikit, 2002).

The fifth dimension, empathy (including access, communication and understanding the customer), relates to the provision of caring and personalized attention to customers (Alnsour et al., 2014). It has been identified as a significant determinant of customer value (Wang and Lo, 2002).

The sixth common dimension, network aspect, refers to the clarity of voice and the area coverage (Santouridis and Trivellas, 2010) plus frequency of dropped calls (Kumar and Lim, 2008; Negi, 2009). Network quality is one of the most basic services offered by a mobile service provider and is important for both voice calls and data services (Kumar and Lim, 2008). The literature review revealed that network aspect is a significant determinant of customer satisfaction and customer value (Wang and Lo, 2002) and a significant determinant of customer loyalty (Santouridis and Trivellas, 2010).

The seventh common dimension, customer service, refers to the series of activities for servicing customers before, during and after a purchase, including the after sales service, flexible-price policy, technique support and training (Chen and Yang, 2015). It is the success of problem resolution, the courtesy of customer service representatives, the help provided by call-centers and the provision of consistent advice (Santouridis and Trivellas, 2010). It has been identified as a significant determinant of customer satisfaction and loyalty (Santouridis and Trivellas, 2010) and perceived value (Kuo et al., 2009).

The eighth common dimension, convenience, refers to easiness of subscribing and changing service, and staff friendliness, when subscribing and changing (Kim et al., 2004). It has been identified as the most significant determinant of overall service quality and a significant determinant of relationship quality with the customers and customer loyalty (Abdel-Rahman, 2012).

However, other quality dimensions have been identified by researchers; value-added services, entertainment services, data services, mobile device, pricing structure, billing, interaction quality, customer service quality, service provision, environment quality, outcome quality, information and content quality, corporate image, vendor, campaign, advertisement. Liang et al. (2013) identified seven critical factors, listed in descending order of influence, that cause customers to switch mobile phone service providers: core service failure, high price, ethical problems, competition, inconvenience, service encounter failure, and influence from family/friends/group.

Little effort has been made by the authors reviewed here to examine the structures for 
telecommunications service quality. Only two hierarchical multi-dimensional models of telecommunications service quality were found ( $\mathrm{Lu}$ et al., 2009; Chen and Yang, 2015). Two other hierarchical models were developed for measuring mobile banking SQ (Arcand et al. 2017; Jun and Palacios, 2016) and one for mobile health services (Akter et al., 2010).

\subsection{New mobile services quality}

With the development of such handheld devices as personal digital assistants, tablets, and smart phones, wireless and mobile technologies and their associated applications have become essential for daily life. According to the International Telecommunication Union (ITU), there were 7,74 billion mobile subscribers in 2017, a number equivalent to $103.5 \%$ of the world's population (ITU, 2017).

These figures imply the very rapid evolution of internet access and the mobile market, with ever-increasing numbers of people using handheld devices. Advanced and mature mobile communication technologies have facilitated the development of a variety of mobile applications, including locationbased services, mobile reading services, electronic books, mobile TV, and mobile music. Recently, there have been many research projects directed to measure the service quality of new services provided through the technology of mobile networks (e.g. mobile education, mobile health services, mobile commerce, and mobile banking) (Arcand et al., 2017; Huang et al., 2015; Akter et al., 2010).

Jun and Palacios (2016) identified mobile banking application quality (mobile convenience, accuracy, diverse mobile application service feature, ease of use, control, speed, aesthetics and security), and mobile banking customer service quality (continuous improvement, competence, credibility, courtesy, understanding the customer, communication, reliability, access and responsiveness) as the key SQ dimensions in the case of mobile banking. Again Arcand et al. (2017) identified utilitarian dimensions (security/privacy and practicity), and hedonic dimensions (design/aesthetics, sociality and enjoyment) as the key SQ dimensions of mobile banking.

Huang et al. (2015) identified efficiency, system availability, content, privacy, fulfillment, responsiveness, compensation, contact, and billing as the key SQ dimensions in the case of mobile commerce services. For mobile health services quality, Akter et al. (2010) identified platform quality (system reliability, system availability, system efficiency, and system privacy), interaction quality (responsiveness, assurance, and empathy) and outcome quality (functional benefit, and emotional benefit).

\section{Conclusion}

This paper aimed to analyze the service quality dimensions and models established in various empirical studies and applied to telecommunications services. It is apparent from this review that certain general observations can be made regarding the dimensionality and structure of the telecommunications service quality as presented in these researches.

It is very clear that there is no consensus on the number and nature of the dimensions of the telecommunications SQ construct but globally eight dimensions recur more consistently ('reliability', 'tangibles', 'responsiveness', 'assurance', 'empathy', 'network', 'customer service', and 'convenience',). It is thus apparent that the five SERVQUAL dimensions constitute key factors in the telecommunications context. Of the 22 studies, 8 adopted SERVQUAL/modified SERVQUAL. Some of the telecommunications SQ dimensions in this review are identical (or at least similar) to those reported for conventional service 
quality. The researches reviewed here concentrate on functional quality and only a few researches deal with outcome quality.

In the conventional service context, measurements of service quality have focused primarily on the interactions of consumers with the firm employees (humanhuman encounters) during delivery and consumption of a service besides using some marketing mix variables. On the other hand for this technology-enabled service, measures of service quality focus mainly on consumer interactions with the technology beside human based interactions.

Despite the general support for a hierarchical multi-dimensional model of service quality, little effort is made by the authors reviewed here to examine the structures for telecommunications service quality. This literature review lends support to the contention that the dimensionality of SERVQUAL and importance of the dimensions vary with the cultural and country context even within the telecommunications industry.

Recently, there have been many research projects directed to measure the service quality of new services provided through the technology of mobile networks (e.g. mobile education, mobile health services, mobile commerce, and mobile banking).

\section{Limitations and future scope of research}

This paper reviews only empirical studies based on survey data and statistical methods of analysis since 2001 till 2017. It may not have enabled a complete coverage of all existing articles in the field of telecommunications service quality. Yet, the review process covered a large proportion of studies available. A complete coverage of all existing articles in the field of telecommunications service quality would be so difficult and almost impossible. Again the paper focuses on analyzing the dimensions of telecommunications service quality models to find out the direction of research in this field.

- A comprehensive in-depth content analysis that focuses on scales development; mode of administration and scores used; and method adoption, would be suitable for another research.

- Future studies need to consider the quality factors for novice and longterm customer cohorts so that the factors could be identified leading to an improvement in the overall quality of telecommunications.

- Future studies should focus on developing service quality models of new services provided through the technology of mobile networks (e.g. mobile education, mobile health services, mobile commerce, and mobile banking).

- The components of service quality and overall service offering should encompass not only the identified construct (e.g. core, relational), but also constructs/items that reflect the service offering, i.e. it should focus on complete service package.

- More studies on assessment of service quality from the management perspectives would help understand and enhance the concept and implementation of service quality.

- More studies are needed to measure service quality within the Arab countries of the Middle East and compare its results with international studies. 
Abd-Elrahman, A.H. (2012). Measuring Service Quality and Its Impact on Relationship Quality with the Customers and Their Loyalty to the Organization. Master thesis, Productivity and Quality Institute, The Arab Academy for Science \& Technology and Maritime Transport, Cairo, Egypt.

Akter, S., D'Ambra, J. and Ray P. 2010. Service Quality of mHealth: development and validation of a hierarchical model using PLS. Electronic Markets, 20 (3-4), 209-227.

Alnsour, M.S., Abu Tayeh, B. and Alzyadat, M.A. (2014). Using SERVQUAL to assess the quality of service provided by Jordanian telecommunications Sector. International Journal of Commerce and Management, 24 (3), 209 - 218.

Arcand, M., PromTep, S., Brun, I and Rajaobelina, L. (2017). Mobile banking service quality and customer relationships. International Journal of Bank Marketing, 35 (7), 1066-1087.

Athanassopoulos, A.D. and Iliakopoulos, A. (2003). Modeling customer satisfaction in telecommunications: assessing the effects of multiple transaction points on the perceived overall performance of the provider. Production and Operations Management, Vol. 12 No.

Aydin, S. and Ozer, G. (2005). National customer satisfaction indices: an implementation in the Turkish mobile telephone market. Marketing Intelligence \& Planning, 23 (5), 486-504.

Brady, M.K. and Cronin, J.J. Jr (2001). Some new thoughts on conceptualizing perceived service quality: a hierarchical approach. Journal of Marketing, 65 (3), 34-49.

Chen, L.-K. and Yang, W.-N. (2015). Perceived service quality discrepancies between telecommunication service provider and customer. Computer Standards \& Interfaces, 41, 85-97.

Cronin, J.J. Jr and Taylor, S.A. (1992). Measuring service quality: a reexamination and extension. Journal of Marketing, 56 (3), 55-68.

Dabholkar, P.A., Thorpe, D.I. and Rentz, J.O. (1996). A measure of service quality for retailing stores: scale development and validation. Journal of the Academy of Marketing Science, 24 (1), 3-16.

Garvin, D.A. (1987). Competing on the eight dimensions of quality. Harvard Business Review, 65 (6).

Ghobadian, A., Speller, S. and Jones, M. (1994). Service quality concepts and Models. International Journal of Quality \& Reliability Management, 11 (9), 43-66.

Grönroos, C. (1984). A service quality model and its marketing implications. European Journal of Marketing, 18 (4), 36-44.

Huang, E.Y., Lin, S.-W. and Fan, Y.-C. (2015). M-S-QUAL: Mobile service quality measurement. Electronic Commerce Research and Applications 14, 126-142.

International Telecommunication Union (ITU) (2017, October). Key ICT indicators for developed and developing countries and the world. Retrieved October 20, 2017 from

http://www.itu.int/en/ITU- D/Statistics/Pages/facts/default.aspx

Jiang, Y., and Wang, C.L. (2006). The impact of effect on service quality and satisfaction: the moderation of service contexts. Journal of Services Marketing, 20 (4), 211-218.

Johnson, W.C. and Sirikit, A. (2002). Service quality in the Thai telecommunication industry: a tool for achieving a sustainable competitive advantage. Management Decision, 40 (7), 693701.

Jun, M. and Palacios, S. (2016). Examining the key dimensions of mobile banking service quality: an exploratory study. International Journal of Bank Marketing, 34 (3), 307-326.

Kim, M.K., Park, M.C. and Jeong, D.H. (2004). The effects of customer satisfaction and switching barrier on customer loyalty in Korean mobile telecommunication services. 
Telecommunications Policy, 28 (2), 145-59.

Kumar, A. and Lim, H. (2008). Age differences in mobile service perceptions: comparison of Generation Y and baby boomers. Journal of Services Marketing, 22 (7), 568 - 577.

Kuo, Y.F., Wu, C.M. and Deng, W.J. (2009). The relationships among service quality, perceived value, customer satisfaction, and post-purchase intention in mobile value-added services. Computers in Human Behavior, 25, 887-896.

Lehtinen, U. and Lehtinen, J.R. (1982). Service quality: a study of quality dimensions, working paper. Service Management Institute, Helsinki.

Leisen, B. and Vance, C. (2001). Cross-national assessment of service quality in the telecommunication industry: evidence from the USA and Germany. Managing Service Quality: An International Journal, 11 (5), 307 - 317.

Liang, D., Ma, Z. and Qi, L. (2013). Service quality and customer switching behavior in China's mobile phone service sector. Journal of Business Research 66, 1161-1167.

Lu, Y. Zhang, L. and Wang, B. (2009). A multidimensional and hierarchical model of mobile service quality. Electronic Commerce Research and Applications 8, 228-240.

Madu, C.N. and Madu, A.A. (2002). Dimensions of e-quality. International Journal of Quality \& Reliability Management, 19 (3), 246-58.

Negi, R. (2009). User's perceived service quality of mobile communications: experience from Ethiopia. International Journal of Quality \& Reliability Management, 26 (7), 699-711.

Omachonu, V., Johnson, W.C., and Onyeaso, G. (2008). An empirical test of the drivers of overall customer satisfaction: evidence from multivariate Granger causality. Journal of Services Marketing, 22 (6), 434 - 444.

Ozer, A., Argan, M.T. and Argan, M. (2013). The effect of mobile service quality dimensions on customer satisfaction. Procedia - Social and Behavioral Sciences, 99, 428 - 438.

Parasuraman, A., Zeithaml, V.A. and Berry, L.L. (1985). A conceptual model of service quality and its implications for future research. Journal of Marketing, 49 (4), 41 - 50.

Parasuraman, A., Zeithaml, V.A. and Berry, L.L. (1988). SERVQUAL: a multiple-item scale for measuring consumer perceptions of service quality. Journal of Retailing, 64 (1), 12-40.

Pina, V., Torres, L. and Bachiller, P. (2014). Service quality in utility industries: the European telecommunications sector. Managing Service Quality: An International Journal, 24 (1), 2 22.

Roberts, K., Varki, S. and Brodie, R. (2003). Measuring the quality of relationships in consumer services: an empirical study. European Journal of Marketing, 37 (1/2), 169-96.

Sangeetha, J. and Mahalingam, S. (2011). Service quality models in banking: a Review. International Journal of Islamic and Middle Eastern Finance and Management, 4 (1), 83 103.

Santos, J. (2003). E-service quality: a model of virtual service quality Dimensions. Managing Service Quality, 13 (3), 233-46.

Santouridis, I. and Trivellas, P. (2010). Investigating the impact of service quality and customer satisfaction on customer loyalty in mobile telephony in Greece. The TQM Journal, 22 (3), 330-343.

Storbacka, K., Strandvik, T. and Grönroos, C. (1994). Managing customer relationships for profit: the dynamics of relationship quality. International Journal of Service Industry Management, 5 (5), 21-38.

Ueltschy, L., Laroche, M., Eggert, A., and Bindl, U. (2007). Service quality and satisfaction: an international comparison of professional Services perceptions. Journal of Services Marketing, 21 (6), 410 - 423.

Van der Wal, R.W.E., Pampallis, A. and Bond, C. (2002). Service quality in a cellular 
DIIA I IT

WIIESIFAIDQIItelecommunications company: a South African experience. Managing Service Quality: An International Journal, 12 (5), 323 - 335.

Wang, Y. and Lo, H.P. (2002). Service quality, customer satisfaction and behavior intentions evidence from China's telecommunication industry. Info, 4 (6), 50- 60.

Zhao, L., Lu, Y., Zhang, L. and Chau, P.Y.K. (2012). Assessing the effects of service quality and justice on customer satisfaction and the continuance intention of mobile value-added services: An empirical test of a multidimensional model. Decision Support Systems 52, 645656.

\footnotetext{
Abd-Elrahman

Ain Shams University,

Faculty of Commerce,

Egypt,

abdohassanein123@gmail.com
} 